\begin{tabular}{c|c|c}
\hline \hline $\begin{array}{c}\text { Vol. 32(3):299-307 } \\
\text { DOI: } 10.4217 / \text { OPR.2010.32.3.299 }\end{array}$ & Ocean and Polar Research & September 2010 \\
\hline \hline
\end{tabular}

\title{
Article
}

\author{
동해 울릉분지에서 대륙사면과 분지 퇴적물의 \\ 지화학적 특성에 따른 황산염 환원 비교 \\ 유옥례 ${ }^{1} \cdot$ 목진숙 $^{1} \cdot$ 김성한 $^{1} \cdot$ 최동림 $^{2} \cdot$ 현정호 $^{1^{*}}$ \\ ${ }^{1}$ 한양대학교 과학기술학부 해양환경과학과 \\ (426-791) 경기도 안산시 상록구 사3동 1271 \\ 2한국해양연구원 남해연구소 \\ (656-830) 거제군 장목면 장목리 391
}

\section{Comparison of Sulfate Reduction Rates Associated with Geochemical Characteristics at the Continental Slope and Basin Sediments in the Ulleung Basin, East Sea}

\author{
Ok-Rye You ${ }^{1}$, Jin-Sook Mok ${ }^{1}$, Sung-Han Kim ${ }^{1}$, Dong-Lim Choi ${ }^{2}$, and Jung-Ho Hyun ${ }^{{ }^{*}}$ \\ ${ }^{I}$ Department of Environmental Marine Sciences, College of Science and Technology \\ Hanyang University, Ansan 426-791, Korea \\ ${ }^{2}$ South Sea Research Institute, KORDI \\ Geoje 656-830, Korea
}

\begin{abstract}
In conjunction with geochemical characteristics, rate of sulfate reduction was investigated at two sediment sites in the continental slope and rise (basin) of the Ulleung Basin in the East Sea. Geochemical sediment analysis revealed that the surface sediments of the basin site (D2) were enriched with manganese oxides $\left(348 \mu \mathrm{mol} \mathrm{cm}{ }^{-3}\right)$ and iron oxides $\left(133 \mu \mathrm{mol} \mathrm{cm}{ }^{-3}\right)$, whereas total reduced sulfur (TRS) in the solid phase was nearly depleted. Sulfate reduction rates (SRRs) ranged from 20.96 to $92.87 \mathrm{nmol} \mathrm{cm}^{-3} \mathrm{~d}^{-1}$ at the slope site (M1) and from 0.65 to $22.32 \mathrm{nmol} \mathrm{cm}^{-3} \mathrm{~d}^{-1}$ at the basin site (D2). Depth integrated SRR within the top $10 \mathrm{~cm}$ depth of the slope site (M1;5.25 $\mathrm{mmol} \mathrm{m}^{-2} \mathrm{~d}^{-1}$ ) was approximately 6 times higher than that at the basin site (D2; $\left.0.94 \mathrm{mmol} \mathrm{m}^{-2} \mathrm{~d}^{-1}\right)$ despite high organic content $(>2.0 \%$ dry wt.) in the sediment of both sites. The results indicate that the spatial variations of sulfate reduction are affected by the distribution of manganese oxide and iron oxide-enriched surface sediment of the Ulleung Basin.
\end{abstract}

Key words : sulfate reduction, manganese oxide, iron oxide, continental margin, Ulleung Basin

1. 서 론

대륙주변부 해양에서 대륙사면과 대륙대는 해양 전체 표면적의 약 $15 \%\left(47 \times 10^{6} \mathrm{~km}^{2}\right)$ 정도에 불과하지만(Reimers

*Corresponding author. E-mail : hyunjh@hanyang.ac.kr et al. 1992; Wollast 2002), 전체 일차생산의 약 30\% 정도 가 대륙주변부의 수층에서 일어나는 것으로 나타나 유기 물 생산력이 매우 높은 지역에 해당한다(Wollast 1998). 또한 수층에서의 높은 일차생산력으로 인해 퇴적물로의 탄소 침강 플럭스(flux)가 외해에 비해 높으며(Walsh 1991; Wollast 1991; Antoine et al. 1996), 퇴적물로 유입 
되는 유기물의 양이 많기 때문에 유기물 분해율이 높은 지역이다(Jahnke et al. 1990). 수층의 일차생산에 의해 생 성된 유기물은 심층으로 침강하는 동안 수층 내에서 분해 되거나, 퇴적물로 가라앉아 다양한 전자수용체를 이용하 는 미생물들에 의해 분해된다. 유기물 분해에 의해 생성된 무기물은 다시 수층으로 재순환(recycling)하게 되고, 분해 가 이루어지지 않은 일부 유기물은 퇴적물 내에 묻히거나 (buried) 외해로 이동된다(Berner 1982; Wollast 1991). 따 라서 대륙주변부는 좁은 면적에도 불구하고 해양에서의 유기물 분해와 탄소 순환에 중요한 역할을 한다(Walsh 1991; Jahnke and Jahnke 2000).

해양 퇴적물 내에서의 유기물 분해는 산소, 질산염, 산 화망간, 산화철 및 황산염을 전자수용체로 이용하는 미생 물들에 의해 일어난다(Thamdrup and Canfield 1996, 2000; Jørgensen 2006). 수층에서 생물 생산력이 높거나 용승(upwelling)이 발생하는 지역 또는 유기탄소의 침강 플럭스가 높은 지역에서는 유기물의 공급이 많아 퇴적물 에서의 산소 투과 깊이는 표층 수 $\mathrm{mm}$ 또는 수 $\mathrm{cm}$ 에 제한 되어 있는 것으로 보고되며(Hensen et al. 2006; Jørgensen and Kasten 2006), 이러한 환경에서 유기물 분해의 대부분 은 혐기성 상태에서 일어난다. 질산염을 전자수용체로 이 용하는 탈질산화의 경우 금속 산화물(산화망간, 산화철)과 황산염을 전자수용체로 이용하는 것보다 열역학적으로 유 리하지만 유기물 농도가 높은 대륙주변부 퇴적물에서는 산소가 빠르게 고갈되면서 질산염의 농도 또한 빠르게 감 소하므로 유기물 분해에서 차지하는 비율이 미미한 것으 로 나타난다(Hensen et al. 2006; Jørgensen 2006). 일반적 으로 해양에서의 황산염 농도는 약 $28 \mathrm{mM}$ 로 다른 전자 수용체의 농도 보다 높기 때문에 대부분의 혐기성 유기물 분해 과정은 황산염 환원 미생물에 의해 주도되며, 황산염 환원은 해양 퇴적물에서 유기물 분해의 가장 중요한 과정 으로 대륙주변부 퇴적물에 침전된 총 유기탄소 분해의 약 $25-50 \%$ 이상을 담당하는 것으로 보고된다(Jørgensen 1982,2006 ; 현 등 2003). 그러나 최근의 분석 방법의 발 달로 망간과 철의 재순환이 활발하게 일어나는 환경에서 는 황산염 환원 대신 망간 및 철 환원에 의한 유기물 분해 의 중요성이 강조되고 있다(Aller 1990; Canfield et al. 1993a, 1993b; Hyun et al. 2007, 2009b).

외국의 경우 대륙주변부 퇴적물에서 미생물에 의한 유 기물 분해능과 분해 경로에 관한 연구가 많이 진행되어 왔다(Canfield et al. 1993a, 1993b; Thamdrup and Canfield 1996; Ferdelman et al. 1999; Weber et al. 2001). 그러나 국내의 경우 연안역이나 갯벌에서의 환경 요인에 따른 유 기물 분해능과 분해 경로에 대한 연구는 활발히 진행되어 왔으나(목 등 2005; 김 등 2007; Hyun et al. 2009b), 대륙 주변부 퇴적물에서의 혐기성 유기물 분해에 관한 연구는
최근에 들어서 비로소 동해 울릉분지에서의 황산염 환원 및 조절요인에 대한 연구가 보고된 바 있다(Lee et al. 2008; Hyun et al. 2010). Hyun et al. (2010)은 울릉분지 의 표층 퇴적물에서 산화망간과 산화철의 농도가 높게 나 타나며, 이로 인해 울릉분지 퇴적물 내에서 망간 환원과 철 환원이 높게 나타날 가능성을 제시하였다. 본 연구는 Hyun et al. (2010)에 의해 제시된 울릉분지의 황산염 환 원의 공간적 변화에 있어 산화망간과 산화철의 영향에 대 한 연장으로서, 퇴적물의 지화학적 요인과 황산염 환원에 대한 보다 섬세한 수직적 분석을 통해 대륙사면과 분지 퇴적물의 지화학적 차이에 따른 황산염 환원의 공간적 변 화에 대하여 토의하기 위한 것이다.

\section{2. 재료 및 방법}

\section{연구지역}

동해는 태평양 북서쪽에 위치해 있으며, 아시아 대륙과

(a)

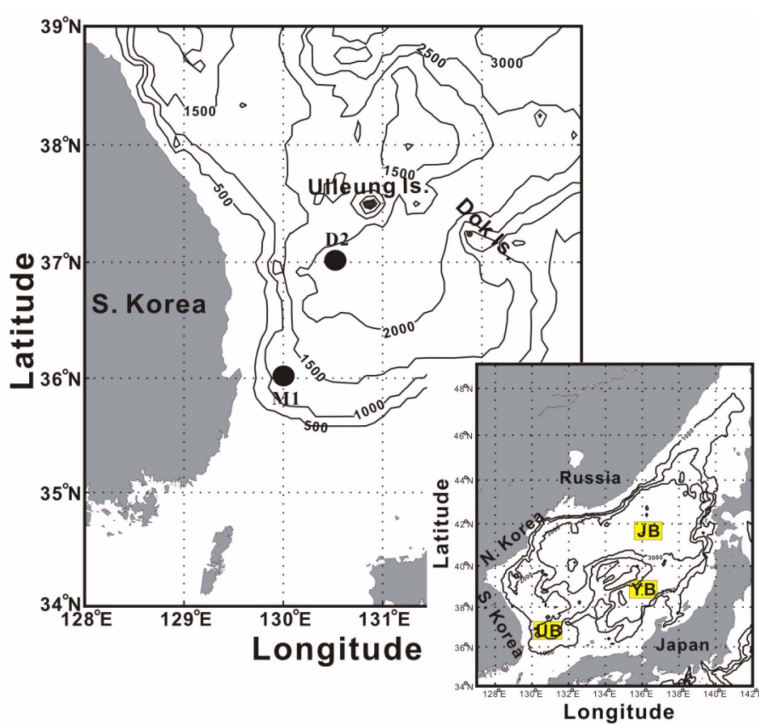

(b)
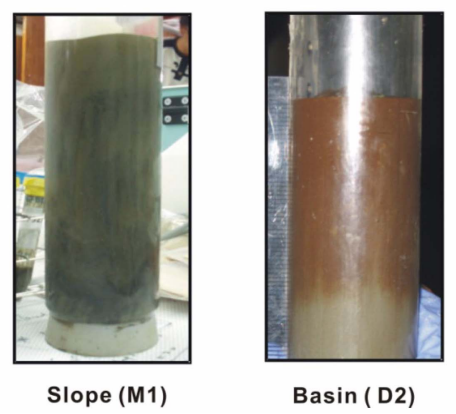

Fig. 1. (a) Map showing sampling sites in the Ulleung Basin (UB), and (b) colors of the surface sediment. The basin site was characterized by a reddish color, whereas the slope site was gray. 
일본 열도 사이에 존재하는 전형적인 대륙주변해(marginal sea)이다. 동해는 우리나라 주변해 가운데 유일하게 수심 $2000 \mathrm{~m}$ 이상되는 심해이며, 동해의 해저지형은 북쪽에 일 본분지(Japan Basin; JB)가 놓여 있고 동쪽에 야마토분지 (Yamato Basin; YB), 그리고 서쪽에 울릉분지(Ulleung Basin; UB)가 위치한다(Fig. 1). 동해의 남서쪽에 위치하 고 있는 울릉분지는 한반도(Korean Peninsula)의 대륙사 면과 일본의 혼슈섬(Honshu Island), 그리고 울릉도 (Ulleung Island)와 독도(Dok Island)에 의해 둘러싸여 있 다(Fig. 1). 울릉분지의 북쪽과 서쪽은 경사가 급한 $\left(>10^{\circ}\right)$ 대륙사면과 접하고 있는 반면, 남쪽과 동쪽은 넓은 대륙붕 과 경사 $\left(1-2^{\circ}\right)$ 가 완만한 대륙사면과 접하고 있다(Park et al. 2005).

\section{시료채취 및 환경요인 분석}

본 연구는 한국해양연구원의 종합해양조사선인 온누리 호를 이용하여 동해 울릉분지 퇴적물에서의 지화학적 성 분 변화에 따른 황산염 환원을 비교하기 위해 대륙사면 (slope; 정점 M1)과 분지(basin; 정점 D2)에서 2009년 3월 에 박스 코어(box core)를 이용하여 시료를 채취하였다 (Fig. 1, Table 1). 박스 코어로 채취한 퇴적물은 선상에서 각 분석 항목별로 아크릴 코어를 이용하여 서브 샘플링 (sub-sampling)을 하였다. 본 연구지역에서 채취한 퇴적물 의 색깔은 대륙사면(M1)에서는 전형적인 저층 퇴적물의 색인 회색을 띠고 있는 반면, 분지(D2)에서는 퇴적물의 표 층이 붉은 갈색을 띠고 있었다(Fig. 1).

퇴적물의 함수율과 공극률을 측정하기 위해 끝을 자른 주사기로 퇴적물 $2 \mathrm{ml}$ 을 취하여 무게를 측정한 뒤 $60^{\circ} \mathrm{C}$ 에 서 2-3일간 건조시킨 후 다시 무게를 측정하였다. 퇴적물 의 부피와 건조 전, 후의 무게로부터 퇴적물의 함수율, 밀 도 및 공극률을 계산하였다. 퇴적물 내의 입자성 유기탄소 (particulate organic carbon; POC) 함량은 퇴적물을 동결 건조시켜 마노사발(agate mortar)로 분말화 시킨 다음 염 산 $(\mathrm{HCl}, 1 \mathrm{~N})$ 으로 무기탄소(inorganic carbon)를 제거한 후 주석용기(tin cup)에 담아 CHNS 원소 분석기 $(\mathrm{GV}$ Instruments, EA1110)로 분석하였다.

\section{공극수 분석}

공극수의 화학 성분 분석을 위해 내경 $6.5 \mathrm{~cm}$, 길이 $25 \mathrm{~cm}$ 의 아크릴 코어를 이용하여 퇴적물을 채취한 후 선

Table 1. Location and water depth of each sampling site

\begin{tabular}{cccc}
\hline Station & $\begin{array}{c}\text { Geographical } \\
\text { region }\end{array}$ & $\begin{array}{c}\text { Depth } \\
\text { (m) }\end{array}$ & Location \\
\hline M1 & Slope & 1453 & $36^{\circ} 10 \mathrm{~N} ; 130^{\circ} 10 \mathrm{E}$ \\
D2 & Basin (Rise) & 2155 & $37^{\circ} 00 \mathrm{~N} ; 130^{\circ} 30 \mathrm{E}$ \\
\hline
\end{tabular}

상 실험실로 운반하였다. 퇴적물을 질소 가스로 충진 된 혐기성 박스 안에서 $1 \mathrm{~cm}$ 간격으로 자른 후 원심분리관에 담고 원심분리 $(3500 \mathrm{rpm}, 10 \mathrm{~min})$ 시켜 혐기성 박스 안에 서 공극수를 취하여 syringe filter(MFS-25, CA, $0.2 \mu \mathrm{m}$ ) 로 부유물을 제거시켰다. 부유물을 제거시킨 공극수는 각 분석 항목별로 나누어 전처리를 하였다.

$\mathrm{CO}_{2}$ 와 $\mathrm{NH}_{4}{ }^{+}$분석을 위해 퇴적물에서 뽑아낸 공극수 중 $2 \mathrm{ml}$ 을 취하여 유리병에 옮긴 후 수은 $\left(\mathrm{HgCl}_{2}, 125 \mathrm{mM}\right)$ $20 \mu \mathrm{l}$ 를 넣어 분석 전까지 냉장 보관하였으며, FIA(flow injection analysis) 방법을 이용하여 분석하였다(Hall and Aller 1992). $\mathrm{SO}_{4}{ }^{2-}$ 의 농도 분석을 위해 퇴적물에서 뽑아 낸 공극수 중 $2 \mathrm{ml}$ 을 취하여 플라스틱 vial에 담고 $20 \mu \mathrm{l}$ 의 진한 염산을 넣은 후 분석 전까지 냉동 보관하였으며, 이 온 크로마토그래피(761 Compact IC, Metrohm)를 이용하 여 농도를 측정하였다. $\mathrm{Mn}^{2+}$ 의 농도는 산 처리된 시료를 질산 $\left(\mathrm{HNO}_{3}, 1 \%\right)$ 으로 희석하여 유도결합 플라즈마 분광 분석기(ICP-OES, Optima $3300 \mathrm{DV}$, Perkin Elmer)로 측 정하였다(Canfield et al. 1993a; Thamdrup and Dalsgaard 2000). $\mathrm{Fe}^{2+}$ 의 농도는 ferrozine buffer $(0.02 \%$ in $50 \mathrm{mM}$ $\mathrm{HEPES}, \mathrm{pH}$ 7)에 산 처리된 시료를 넣고 10 분 동안 $200 \mathrm{rpm}$ 으로 흔들어 준 다음 UV-VIS recording spectrophotometer(UV-2401 PC, Shimadzu)로 측정하여 분석하 였다(Stookey 1970).

\section{총 산화망간 및 고체상 철, 총 환원황 성분 분석}

총 산화망간(total extractable $\mathrm{Mn}$ )은 건조된 퇴적물에 dithionite-citrate-acetic acid(DCA, $\mathrm{pH} 4.8$ )를 넣고 4시간 동안 $200 \mathrm{rpm}$ 으로 흔들어 준 다음 원심분리 $(3500 \mathrm{rpm}$, $10 \mathrm{~min}$ 시켜 상등액을 취하여 유도결합 플라즈마 분광 분 석기(ICP-OES, Optima $3300 \mathrm{DV}$, Perkin Elmer)로 측정 하였다(Canfield et al. 1993a; Thamdrup and Canfield 1996). 퇴적물 내의 환원된 고체상(solid phase) $\mathrm{Fe}(\mathrm{II})$ 는 혐기성 박스 안에서 oxalate extract solution (ammonium oxalate+oxalic acid)을 이용하여 추출한 후 ferrozine $\operatorname{buffer}(0.02 \%$ in $50 \mathrm{mM}$ HEPES, $\mathrm{pH}$ 7)와 반응시켜 분석 하였다(Phillips and Lovley 1987). 총 산화철(Fe(II)+Fe(III)) 은 완전히 산화시킨 퇴적물을 oxalate extract solution으로 추출한 후 ferrozine buffer $+1 \%$ (w/v) hydroxylamine hydrochloride와 반응시켜 분석하였다(Thamdrup and Canfield 1996). 산화철( $\mathrm{Fe}(\mathrm{III}))$ 은 총 산화철과 환원된 고 체상 철의 차이 값(( $\mathrm{Fe}(\mathrm{II})+\mathrm{Fe}(\mathrm{III}))-\mathrm{Fe}(\mathrm{II}))$ 으로부터 계산하 였다(Gribsholt et al. 2003). 총 환원황(total reduced sulfur; TRS)은 acid volatile sulfide (AVS; $\mathrm{H}_{2} \mathrm{~S}+\mathrm{FeS}$ )와 chromium reducible sulfur $\left(\mathrm{CRS} ; \mathrm{S}^{0}+\mathrm{FeS}_{2}\right)$ 를 총칭하며, 총 환원황의 분석은 single-step chromium reduction 방법 (Fossing and Jørgensen 1989)에 의해 추출된 시료를 $\mathrm{Zn}$ - 
acetate $(20 \%)$ 로 처리한 후 Cline solution과 반응시켜 spectrophotometer로 측정하였다(Parsons et al. 1984).

\section{황산염 환원력}

황산염 환원력 측정을 위해 core injection technique을 이용하였다(Jørgensen 1978). 내경 $2.5 \mathrm{~cm}$, 길이 $35 \mathrm{~cm}$ 의 아크릴 코어를 이용하여 퇴적물을 채취한 후 선상 실험실 로 운반하여 현장온도에서 안정화시켰다. $5 \mu \mathrm{l}$ carrier-free ${ }^{35} \mathrm{SO}_{4}{ }^{2-}($ 약 $2.5 \mu \mathrm{Ci})$ 를 실리콘으로 막아 놓은 주입구 $(1 \mathrm{~cm}$ 간격)를 통해 주입한 후 현장온도 조건에서 11-13시간 동 안 배양하였다. 배양기간 동안 생성된 환원황을 고정하기 위해 $1 \mathrm{~cm}$ 간격으로 자른 퇴적물을 $20 \% \mathrm{Zn}$-acetate 용액 $(10 \mathrm{ml})$ 이 담긴 $50 \mathrm{ml}$ 원심분리관에 넣고 잘 흔들어 분석 전까지 냉동 보관하였다. $\mathrm{Zn}$-acetate 용액에 보관된 퇴적 물로부터 ${ }^{35} \mathrm{~S}$ 를 추출하기 위해 single-step chromium reduction 방법을 이용하였다(Fossing and Jørgensen 1989).

\section{3. 결 과}

\section{환경 요인}

퇴적물의 밀도는 정점 $\mathrm{M} 1$ 에서 $1.18-1.38 \mathrm{~g} \mathrm{~cm}^{-3}$, 정점 $\mathrm{D} 2$ 에서 $1.20-1.33 \mathrm{~g} \mathrm{~cm}^{-3}$ 의 범위로 조사되었고, 공극률은 정점 $\mathrm{M} 1$ 에서 0.82-0.97, 정점 $\mathrm{D} 2$ 에서 0.93-0.95의 범위로 조사되어 퇴적물의 밀도와 공극률은 정점 $\mathrm{M} 1$ 과 정점 $\mathrm{D} 2$ 에서 큰 차이를 보이고 있지 않았다(data not shown). 정 점 $\mathrm{M} 1$ 과 정점 $\mathrm{D} 2$ 퇴적물에서 표층 $2 \mathrm{~cm}$ 까지 평균한 입 자성 유기탄소 함량은 각각 $2.69 \%, 2.08 \%$ 로 나타났다 (Fig. 3, Table 2).

\section{공극수 내 지화학 성분}

공극수 내 $\mathrm{CO}_{2}$ 농도는 정점 $\mathrm{M} 1$ 에서 $2.46-3.41 \mathrm{mM}$, 정 점 $\mathrm{D} 2$ 에서 $2.34-2.82 \mathrm{mM}$ 의 범위로 깊이가 깊어질수록 증가하는 경향으로 나타났으며, 정점 $\mathrm{D} 2$ 보다 정점 $\mathrm{M} 1$ 에 서 깊이에 따른 증가율이 큰 것으로 나타났다(Fig. 2). $\mathrm{NH}_{4}{ }^{+}$농도는 정점 $\mathrm{M} 1$ 에서 $47.59-235.60 \mu \mathrm{M}$, 정점 $\mathrm{D} 2$ 에 서 35.75-95.73 $\mu \mathrm{M}$ 의 범위로 깊이가 깊어질수록 증가하 는 경향으로 나타났으며, 정점 $\mathrm{D} 2$ 보다 정점 $\mathrm{M} 1$ 에서 깊 이에 따른 증가율이 더 큰 것으로 나타났다(Fig. 2). 또한 $\mathrm{NH}_{4}{ }^{+}$농도를 표층에서부터 $10 \mathrm{~cm}$ 까지 누적한 결과 정점 $\mathrm{D} 2\left(4.21 \mathrm{mmol} \mathrm{m}^{-2}\right)$ 보다 정점 $\left.\mathrm{M} 1(8.38 \mathrm{mmol} \mathrm{m})^{-2}\right)$ 에서 약 2 배 높게 나타났다(Table 2). 이처럼 유기물 분해 산물 인 $\mathrm{CO}_{2}$ 와 $\mathrm{NH}_{4}{ }^{+}$를 측정한 결과 정점 $\mathrm{D} 2$ 보다 정점 $\mathrm{M} 1$ 에 서 상대적으로 유기물 분해가 활발히 일어나는 것으로 나 타났다. $\mathrm{SO}_{4}{ }^{2-}$ 농도는 평균 $28.35 \pm 0.88 \mathrm{mM}$ 로 정점이나 깊이에 따른 뚜렷한 차이는 나타나지 않았다(data not
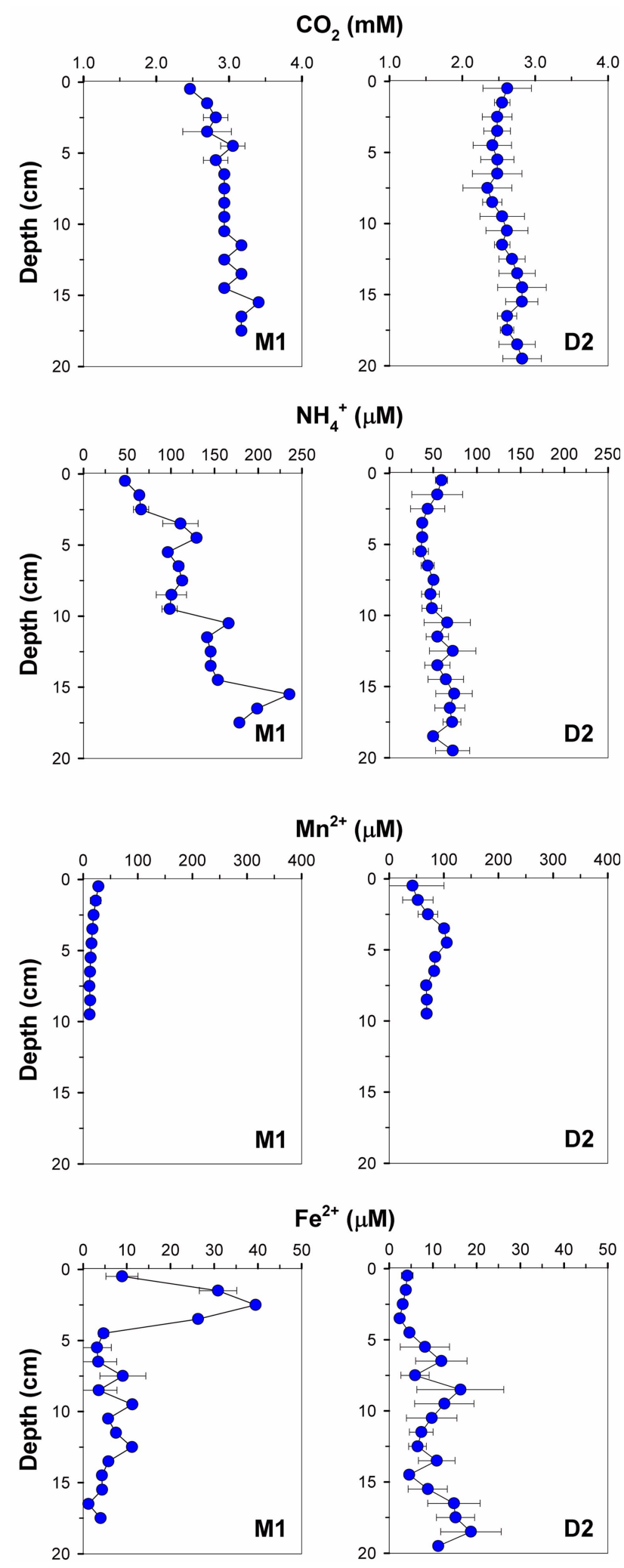

Fig. 2. Vertical profiles of pore water constituents in the sediments of slope (M1) and basin (D2). Error bars represent the mean \pm 1 SD from triplicate cores. 
Table 2. Depth-integrated $(0-10 \mathrm{~cm})$ inventories of the pore water, solid phase constituents and sulfate reduction rates (SRR) in the sediments of slope (M1) and basin (D2)

\begin{tabular}{|c|c|c|c|c|c|c|c|c|c|c|c|}
\hline \multirow[b]{2}{*}{ Station } & \multicolumn{4}{|c|}{ Pore water $\left(\mathrm{mmol} \mathrm{m}^{-2}\right)$} & \multicolumn{6}{|c|}{ Solid phase $\left(\mathrm{mmol} \mathrm{m}^{-2}\right)$} & \multirow[b]{2}{*}{$\begin{array}{c}\text { SRR } \\
\left(\mathrm{mmol}^{-2} \mathbf{d}^{-1}\right)\end{array}$} \\
\hline & $\mathrm{CO}_{2}$ & $\mathrm{NH}_{4}^{+}$ & $\mathbf{M n}^{2+}$ & $\mathrm{Fe}^{2+}$ & $\begin{array}{l}\text { Corg* } \\
(\% \text { dw) }\end{array}$ & $\begin{array}{c}\text { Total } \\
\text { extractable } \\
\text { Mn }\end{array}$ & $\mathbf{F e}(\mathrm{II})$ & $\mathrm{Fe}(\mathrm{III})$ & $\begin{array}{c}\mathbf{F e} \\
(\text { III+III) }\end{array}$ & TRS & \\
\hline M1 & 254.50 & 8.38 & 1.51 & 1.28 & 2.69 & 126 & 1031 & 111 & 817 & 780 & 5.25 \\
\hline D2 & 227.91 & 4.21 & 6.83 & 0.67 & 2.08 & 8529 & 1047 & 4913 & 5858 & 150 & 0.94 \\
\hline
\end{tabular}

*Inventories of organic carbon contents (\% dry weight) were obtained from top $2 \mathrm{~cm}$ depth of sediments.

shown). $\mathrm{Mn}^{2+}$ 농도는 정점 $\mathrm{M} 1$ 에서 $11.80-27.90 \mu \mathrm{M}$, 정 점 $\mathrm{D} 2$ 에서 $42.62-105.36 \mu \mathrm{M}$ 의 범위로 조사되었으며, 정 점 $\mathrm{M} 1$ 에서는 깊이에 따라 농도 변화 없이 균일한 수직 분 포로 나타난 반면, 정점 $\mathrm{D} 2$ 에서는 깊이가 깊어질수록 증 가하였다(Fig. 2). $\mathrm{Mn}^{2+}$ 농도를 표층에서부터 $10 \mathrm{~cm}$ 까지 누적한 결과 정점 $\mathrm{M} 1\left(1.51 \mathrm{mmol} \mathrm{m} \mathrm{m}^{-2}\right)$ 보다 정점 $\mathrm{D} 2$ $\left(6.83 \mathrm{mmol} \mathrm{m}^{-2}\right)$ 에서 약 5 배 높게 나타났다(Table 2). $\mathrm{Fe}^{2+}$ 농도는 정점 $\mathrm{M} 1$ 에서 $1.25-39.46 \mu \mathrm{M}$, 정점 $\mathrm{D} 2$ 에서 2.40-18.71 $\mu \mathrm{M}$ 의 범위로 조사되었으며, 특히 정점 $\mathrm{M} 1$ 은 표층 2-3 cm 깊이에서 농도가 가장 높았고 $5 \mathrm{~cm}$ 깊이까지 농도가 급격히 감소하였다(Fig. 2). $\mathrm{Fe}^{2+}$ 농도를 표층에서 부터 $10 \mathrm{~cm}$ 까지 누적한 결과 정점 $\mathrm{D} 2\left(0.67 \mathrm{mmol} \mathrm{m}^{-2}\right)$ 보 다 정점 $\mathrm{M} 1\left(1.28 \mathrm{mmol} \mathrm{m} \mathrm{m}^{-2}\right)$ 에서 약 2배 높게 나타났다 (Table 2).

\section{퇴적물 내 총 산화망간 및 고체상 철, 총 환원황 성분}

총 산화망간 농도는 정점 $\mathrm{M} 1$ 에서 $0.78-3.21 \mu \mathrm{mol} \mathrm{cm}{ }^{-3}$, 정점 $\mathrm{D} 2$ 에서 $1.32-348.24 \mu \mathrm{mol} \mathrm{cm}{ }^{-3}$ 의 범위로 조사되었 다(Fig. 3). 정점 $\mathrm{M} 1$ 에서는 깊이에 따라 균일한 수직 분포 로 나타난 반면, 정점 $\mathrm{D} 2$ 에서는 표층에서 가장 높은 값으 로 나타났고 $4 \mathrm{~cm}$ 깊이까지 급격히 감소하였으며 그 이하 깊이에서는 균일한 수직 분포로 나타났다(Fig. 3). 총 산화 망간 농도를 표층에서부터 $10 \mathrm{~cm}$ 까지 누적한 결과 정점 $\mathrm{M} 1\left(126 \mathrm{mmol} \mathrm{m} \mathrm{m}^{-2}\right)$ 보다 정점 $\mathrm{D} 2\left(8529 \mathrm{mmol} \mathrm{m}^{-2}\right)$ 에서 약 68배 높게 나타났다(Table 2). 총 산화철의 농도는 정 점 $\mathrm{M} 1$ 에서 4.26-14.09 $\mu \mathrm{mol} \mathrm{cm}{ }^{-3}$ 의 범위로 균일한 수직 분포로 나타난 반면, 정점 $\mathrm{D} 2$ 에서는 20.11-132.15 $\mu \mathrm{mol}$ $\mathrm{cm}^{-3}$ 의 범위로 표층에서부터 $2-3 \mathrm{~cm}$ 깊이까지 급격하게 증가하는 경향으로 나타났다(Fig. 3). 고체상 철을 표층에 서부터 $10 \mathrm{~cm}$ 까지 누적한 결과 철 환원의 전자수용체로 사용되는 $\mathrm{Fe}(\mathrm{III})$ 는 정점 $\mathrm{M} 1\left(111 \mathrm{mmol} \mathrm{m}^{-2}\right)$ 보다 정점 $\mathrm{D} 2\left(4913 \mathrm{mmol} \mathrm{m} \mathrm{m}^{-2}\right)$ 에서 약 44배 높게 나타났으며, 환원 된 형태인 $\mathrm{Fe}(\mathrm{II})$ 는 정점 $\mathrm{M} 1$ 과 정점 $\mathrm{D} 2$ 에서 큰 차이를 보 이지 않았다(Table 2). 황산염 환원력의 상대적인 차이를 나타내는 인자로 사용될 수 있는 총 환원황의 농도는 정 점 $\mathrm{M} 1$ 에서 $4.52-28.13 \mu \mathrm{mol} \mathrm{cm}{ }^{-3}$, 정점 $\mathrm{D} 2$ 에서 $0.03-$
$2.12 \mu \mathrm{mol} \mathrm{cm} \mathrm{cm}^{-3}$ 의 범위로 조사되었으며, 정점 $\mathrm{D} 2$ 에서는 깊이에 따라 균일한 수직 분포로 나타난 반면, 정점 $\mathrm{M} 1$ 에 서는 $15 \mathrm{~cm}$ 깊이부터 증가하는 경향으로 나타났다(Fig. 3). 총 환원황의 농도를 표층에서부터 $10 \mathrm{~cm}$ 까지 누적한 결과 정점 $\mathrm{D} 2\left(150 \mathrm{mmol} \mathrm{m}^{-2}\right)$ 보다 정점 $\mathrm{M} 1(780 \mathrm{mmol}$ $\mathrm{m}^{-2}$ )에서 약 5 배 높게 나타났으며(Table 2), 황산염 환원 력 또한 표층에서부터 $10 \mathrm{~cm}$ 까지 누적한 결과 정점 $\mathrm{M} 1$ 에 서 높게 나타났다(Table 2).

\section{황산염 환원력}

황산염 환원력은 정점 $\mathrm{M} 1$ 에서 $20.96-92.87 \mathrm{nmol} \mathrm{cm}{ }^{-3}$ $\mathrm{d}^{-1}$, 정점 $\mathrm{D} 2$ 에서 $0.65-22.32 \mathrm{nmol} \mathrm{cm} \mathrm{c}^{-3} \mathrm{~d}^{-1}$ 의 범위로 조 사되었다(Fig. 4). 정점 $\mathrm{D} 2$ 에서는 깊이에 따라 비교적 균 일한 수직 분포로 나타난 반면, 정점 $\mathrm{M} 1$ 에서는 $2-3 \mathrm{~cm}$ 깊이에서 농도가 가장 높게 나타났다(Fig. 4). 표층에서부 터 $10 \mathrm{~cm}$ 까지 누적한 결과 정점 $\mathrm{D} 2\left(0.94 \mathrm{mmol} \mathrm{m} \mathrm{m}^{-2} \mathrm{~d}^{-1}\right)$ 보다 정점 $\mathrm{M} 1\left(5.25 \mathrm{mmol} \mathrm{m} \mathrm{d}^{-2}\right)$ 에서 약 6 배 높게 나타 났다(Table 2).

\section{4. 토 의}

다양한 퇴적 환경에서 조사된 황산염 환원과 본 연구 지역에서 조사한 황산염 환원을 비교한 결과 울릉분지 퇴 적물에서의 황산염 환원은 대륙붕 $\left(60 \mathrm{mmol} \mathrm{C} \mathrm{m} \mathrm{m}^{-2} \mathrm{~d}^{-1}\right.$; Thamdrup and Canfield 1996)이나 염습지(42.1-92.4 mmol C m ${ }^{-2} \mathrm{~d}^{-1}$; Hyun et al. 2007), 갯벌(37-126 mmol $\mathrm{C} \mathrm{m}^{-2} \mathrm{~d}^{-1}$; Hyun et al. 2009b)에 비해서는 낮은 것으로 나타났지만, 본 연구 지역과 비슷한 수층 깊이를 가지는 Chile 용승지역(5.2-9.1 mmol $\mathrm{C} \mathrm{m}^{-2} \mathrm{~d}^{-1}$; Thamdrup and Canfield 1996)과 Namibia(0.05-1.39 mmol C m $\mathrm{d}^{-2}$; Ferdelman et al. 1999) 용승지역, Black Sea(0.22-0.42 $\mathrm{mmol} \mathrm{C} \mathrm{m} \mathrm{d}^{-2} \mathrm{~d}^{-1}$; Weber et al. 2001)와 같은 대륙주변부 퇴적물에 비해서는 유사하거나 높게 나타났다.

황산염 환원은 수층에서의 일차생산력 규모와 퇴적물 내로 유입되는 유기물의 양에 의해 영향을 받는 것으로 

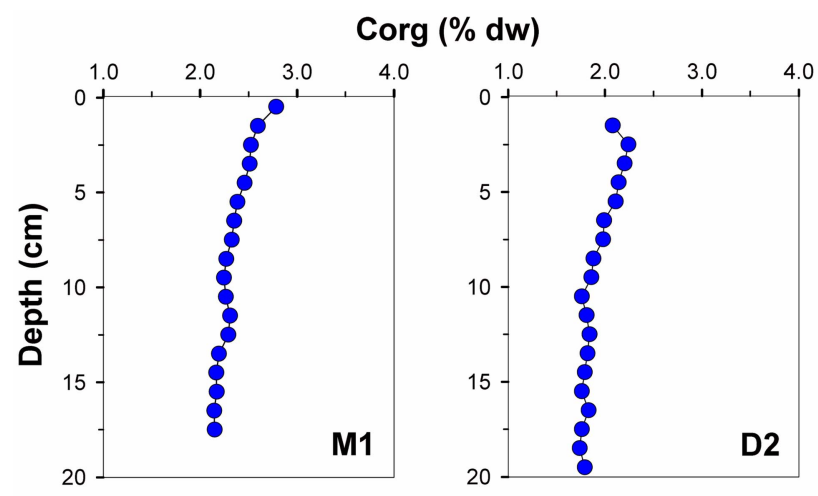

Total Extractable $\mathrm{Mn}\left(\mu \mathrm{mol} \mathrm{cm}^{-3}\right)$
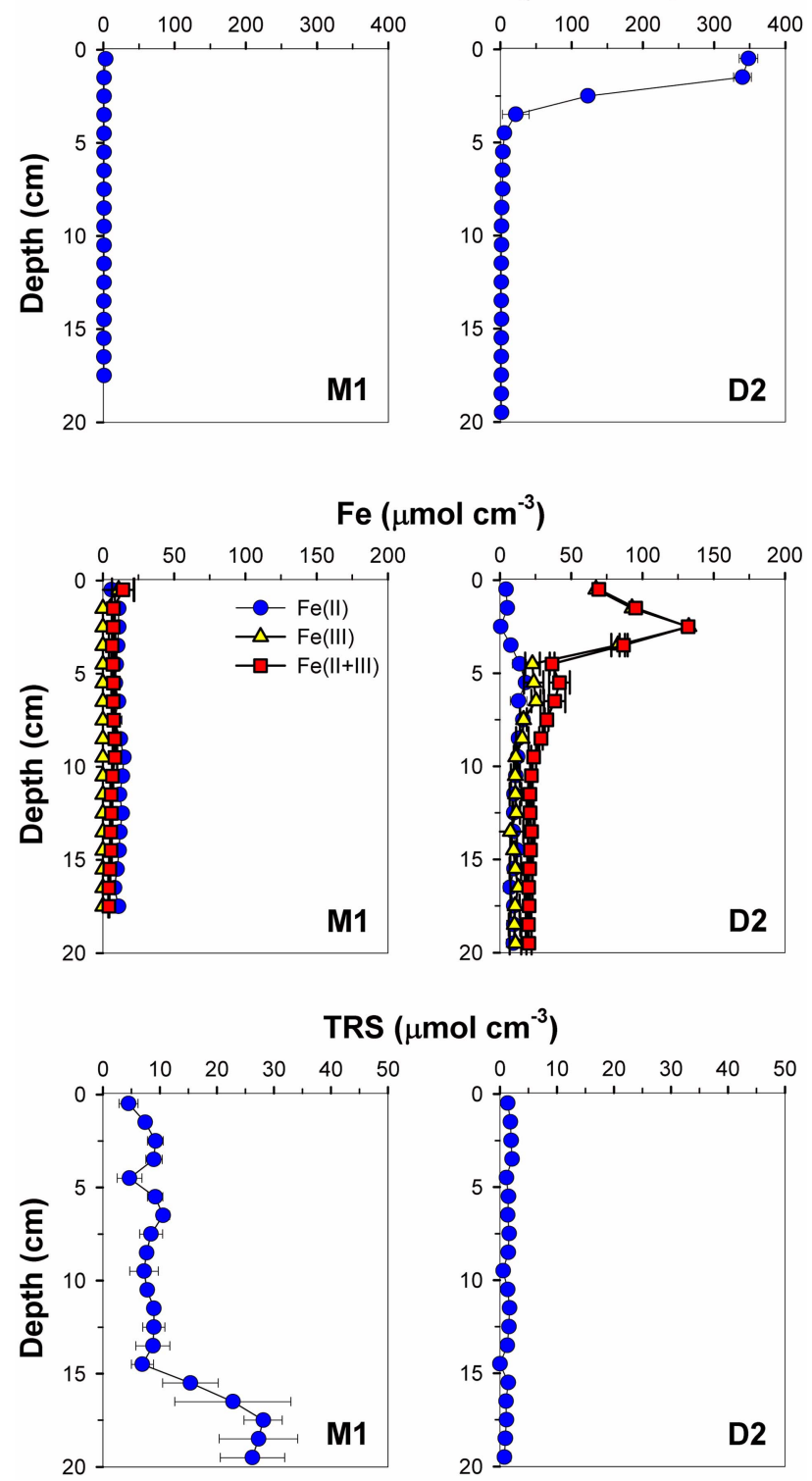

Fig. 3. Vertical profiles of solid phase constituents in the sediments of slope (M1) and basin (D2). Error bars represent the mean \pm 1 SD from triplicate cores.

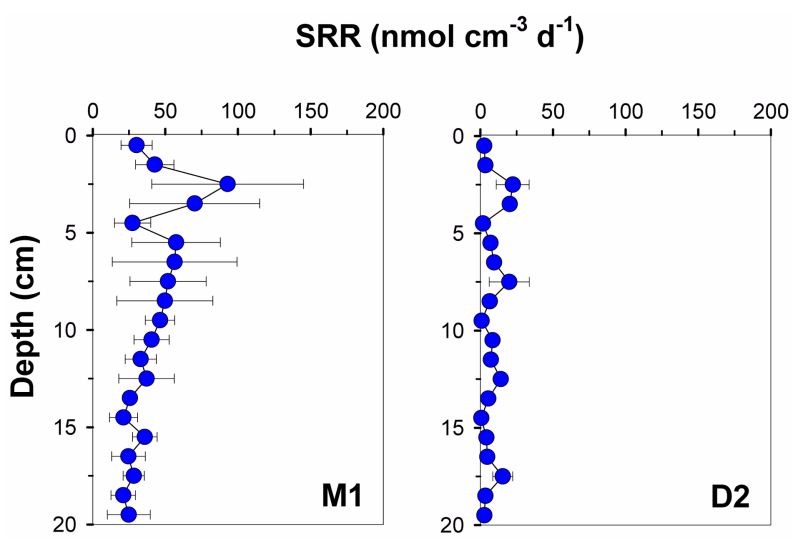

Fig. 4. Vertical profiles of sulfate reduction rates (SRR) in the sediments of slope (M1) and basin (D2). Error bars represent the mean \pm 1 SD from triplicate cores.

보고되고 있다(Canfield 1991; 현 등 2003). 울릉분지의 일차생산력은 동해 남동부의 연안 용승에 의해 생성된 높 은 생물 생산력이 난수성 소용돌이(UWE)를 따라 울릉분 지로 이동되기 때문에(Hyun et al. 2009a), 일본분지와 야 마토분지에 비해서 높게 나타난다(Yamada et al. 2005). 또한 김 등 (2009)은 울릉분지의 유광대에서 일차생산에 의해 생성된 유기탄소가 심층으로 침강하는 비율이 약 $48 \%$ 인 것으로 보고하였고, 이는 전 세계 해역에서 보고된 침강률(6-36\%) 보다 높은 값으로 울릉분지는 유광대에서 생성된 유기탄소가 심층으로 침강하는 비율이 가장 높은 해역들 가운데 하나이다(Benitez-Nelson et al. 2001; Amiel et al. 2002; Moran et al. 2003, 2005; Giuliani et al. 2007; Hung and Gong 2007). 또한, 본 연구에서 퇴적 물의 표층 $2 \mathrm{~cm}$ 까지 평균한 유기탄소 함량은 약 $2.4 \%$ 로 강으로부터 유기물 유입이 많은 강화도 갯벌 $(0.9 \%$; Hyun et al. 2009b)에 비해서는 월등히 높게 나타났으며 특히, 퇴적된 유기물의 기원이 해양 조류(algae)인지 육상 식물 인지를 규명하는 지시자로 사용되고 있는 $\mathrm{C} / \mathrm{N}$ 비가 평균 7.6 으로 울릉분지 퇴적물에 퇴적된 유기물은 해양의 미세 조류 기원이 우세한 것으로 나타났다(Lee et al. 2008). 결 론적으로 울릉분지는 수층에서의 높은 일차생산력과 높은 유기탄소 침강 플럭스에 의한 영향으로 퇴적물 내로 유입 되는 유기물 양이 많은 것으로 사료되며, 이는 본 연구 지 역과 비슷한 수층 깊이를 가지는 다른 대륙주변부 지역에 비해 울릉분지에서 높게 나타나는 황산염 환원에 영향을 주는 것으로 여겨진다.

유기물 분해 경로에 영향을 미치는 주요한 환경 요인들 중에 특히 중요한 것은 퇴적물로 공급되는 유기물 양과 이용 가능한 산화망간, 산화철, 황산염과 같은 전자수용체 의 분포이며, 본 연구 지역과 같이 유기물 공급이 충분할 
경우 망간 환원과 철 환원, 황산염 환원은 이러한 전자수 용체의 분포 여부에 의해 좌우된다(현 등 2003). 일반적으 로 해양 퇴적물에서는 황산염 환원이 상대적으로 우세한 유기물 분해 경로지만, 산화망간과 산화철이 충분히 존재 할 경우 이를 이용하는 망간 환원 미생물과 철 환원 미생 물에 의한 유기물 분해가 황산염 환원 보다 우세하게 나 타나며, 망간 환원 또한 철 환원을 부분적으로 억제하는 것으로 보고되고 있다(Lovley and Phillips 1988; Aller 1990; Canfield et al. 1993a, 1993b; Thamdrup et al. 1994). Canfield et al. (1993b)의 연구에 의하면 퇴적물에 서의 산화철 농도가 산화망간 농도 보다 높은 정점에서는 철 환원이 망간 환원 보다 우세하게 나타났으나 퇴적물 내의 산화망간 농도 $\left(175 \mu \mathrm{mol} \mathrm{cm} \mathrm{cm}^{-3}\right)$ 가 현저히 높은 정점 에서는 망간 환원이 혐기성 유기물 분해의 $99 \%$ 를 차지하 는 것으로 나타나 철 환원과 황산염 환원에 의한 유기물 분해가 거의 이루어지지 않는 것으로 나타났다.

본 연구에서 퇴적물 내의 유기탄소 함량이 대륙사면 $(2.69 \%)$ 과 분지 $(2.08 \%)$ 에서 큰 차이를 보이고 있지 않음 에도 불구하고, 황산염 환원은 대륙사면 $\left(5.25 \mathrm{mmol} \mathrm{m}^{-2}\right.$ $\left.\mathrm{d}^{-1}\right)$ 보다 분지 $\left(0.94 \mathrm{mmol} \mathrm{m} \mathrm{m}^{-2} \mathrm{~d}^{-1}\right)$ 에서 대단히 낮은 것으 로 나타났다(Table 2). 이처럼 황산염 환원이 대륙사면 보 다 분지에서 낮게 나타나는 것은 총 산화망간과 총 산화 철이 대륙사면 보다 분지에서 높은 농도로 존재하기 때문 인 것으로 사료된다(Fig. 3, Table 2). 일반적으로 대륙사 면과 분지에서 나타나는 산화망간과 산화철의 농도 차이 는 망간 환원과 철 환원에 의해 생성된 $\mathrm{Mn}^{2+}$ 와 $\mathrm{Fe}^{2+}$ 가 퇴 적물에서 공극수로 용출된 후 산소에 의해 재산화 되어 다시 $\mathrm{MnO}_{2}$ 와 $\mathrm{FeOOH}$ 의 형태로 표층 퇴적물 내에 재침전 되며, 이러한 반응은 대륙사면을 따라 분지까지 지속적으 로 일어나며 점차 분지 내에 $\mathrm{MnO}_{2}$ 와 $\mathrm{FeOOH}$ 가 축적되는 결과를 가져오게 되기 때문인 것으로 보고되고 있다 (Canfield et al. 1993a, 1993b). 최근 Hyun et al. (2010)은 동해 울릉분지의 대륙사면과 분지 퇴적물 내 황산염 환원 의 지역적인 차이에 대해 토의하였으며, 산화망간과 산화 철의 농도가 높은 분지에서는 0-6 cm 깊이에서 황산염 환 원이 위축되는 것으로 나타나 분지 퇴적물 내에 높은 농 도로 존재하는 산화망간과 산화철을 이용하는 미생물들에 의한 망간 환원과 철 환원의 중요성을 제시하였다. 실제로 본 연구와 비슷한 정점에서 이루어진 미생물 군집 다양성 분석 결과(김 등 2010), 대륙사면에서는 황의 순환과 밀접 한 연관성이 있는 것으로 알려진 고세균 군집(Marine Benthic Group D)이 분지에 비해 높은 비율로 나타난 반 면, 분지 퇴적물에서는 망간의 순환과 연관된 고세균 군집 (Marine Benthic Group C - Manganese archaea)이 상대 적으로 보다 혐기성인 대륙사면의 퇴적물에 비해 월등히 높은 비율로 나타났다. 이는 울릉분지 내 유기물 분해에
관여하는 미생물들의 분포가 원소들의 지화학적 분포에 영향을 받으며, 이로 인해 유기물 분해 경로가 조절되고 있음을 보여주는 증거이다. 결론적으로, 유기물 공급이 충 분한 울릉분지 퇴적물에서 황산염 환원의 지역적인 차이 는 산화망간과 산화철의 분포 여부에 의해 영향을 받는 것으로 여겨지며, 산화망간과 산화철, 황산염과 같은 미생 물들이 이용 가능한 전자수용체의 분포 여부가 혐기성 유 기물 분해 경로에 영향을 주는 것으로 사료된다. 향후, 울 릉분지 내의 유기물 분해 경로의 상대적 중요성 및 그에 따른 탄소, 금속 및 영양염류의 생지화학적 거동을 이해하 기 위해서는 지화학적 특성과 미생물 요인간의 상호작용 에 대한 연구가 병행되어야 할 것으로 인식된다.

\section{사 사}

본 연구는 국토해양부의 EAST-I 프로그램과 심해무인 잠수정 해미래 활용기반 구축 연구(PMS 184B), 한국학술 진흥재단(KRF-2007-313-C00790)의 지원을 받아 수행되 었습니다. 본 논문의 심사를 맡아 수고해 주신 심사위원들 께 감사를 드리며, 본 연구의 현장조사에 도움을 주신 온 누리호의 선장님 이하 승무원 여러분께도 감사의 마음을 전합니다.

\section{참고문헌}

김동선, 최만식, 오혜영, 김경희, 노재훈 (2009) 동해 서남해 역에서 여름철 ${ }^{234} \mathrm{Th} /{ }^{238} \mathrm{U}$ 비평형을 이용한 입자상 유기 탄소 침강플럭스 추정. 한국해양학회지「바다」 14(1):1-9 김보배, 조혜연, 현정호 (2010) $16 \mathrm{~S} \mathrm{rRNA}$ 유전자 분석방법 을 이용한 동해 울릉분지 심해 퇴적물 내 고세균 군집 구 조 및 다양성의 수직분포 특성 연구. Ocean Polar Res Submitted

김성한, 목진숙, 정정호, 장윤영, 최광순, 현정호 (2007) 정체 된 시화 인공습지와 해수유통이 활발한 강화 갯벌에서의 혐기성 유기물 분해능 및 분해경로 비교. 한국습지학회지 9(1):1-11

목진숙, 조혜연, 현정호 (2005) 강화도 남단 갯벌의 혐기성 유기물 분해능과 황산염 환원력 및 저서 동물이 이에 미 치는 잠재적 영향. 한국해양학회지 「바다」 10(1):33-46 현정호, 이홍금, 권개경 (2003) 해양환경의 황산염 환원율 조 절요인 및 유기물 분해에 있어 황산염 환원의 중요성. 한 국해양학회지 「바다」 8(2):210-224

Aller RC (1990) Bioturbation and manganese cycling in hemipelagic sediments. Phil Trans R Soc Lond 331:5168

Amiel D, Cochran JK, Hirschberg DJ (2002) ${ }^{234} \mathrm{Th} /{ }^{238} \mathrm{U}$ disequilibrium as an indicator of the seasonal export flux 
of particulate organic carbon in the North Water. DeepSea Res II 49:5191-5209

Antoine D, André JM, Morel A (1996) Oceanic primary production, 2. Estimation at global scale from satellite (coastal zone color scanner) chlorophyll. Global Biogeochem Cycles 10(1):57-69

Benitez-Nelson C, Buesseler KO, Karl DM, Andrews J (2001) A time-series study of particulate matter export in the North Pacific Subtropical Gyre based on ${ }^{234} \mathrm{Th}:{ }^{238} \mathrm{U}$ disequilibrium. Deep-Sea Res I 48:2595-2611

Berner RA (1982) Burial of organic carbon and pyrite sulfur in the modern ocean: its geochemical and environmental significance. Am J Sci 282:451-473

Canfield DE (1991) Sulfate reduction in deep-sea sediments. Am J Sci 291:177-188

Canfield DE, Thamdrup B, Hansen JW (1993a) The anaerobic degradation of organic matter in Danish coastal sediments: iron reduction, manganese reduction, and sulfate reduction. Geochim Cosmochim Acta 57:3867-3883

Canfield DE, Jørgensen BB, Fossing H, Glud R, Gundersen J, Ramsing NB, Thamdrup B, Hansen JW, Nielsen LP, Hall POJ (1993b) Pathways of organic carbon oxidation in three continental margin sediments. Marine Geology 113:27-40

Ferdelman TG, Fossing H, Neumann K, Schulz HD (1999) Sulfate reduction in surface sediments of the southeast Atlantic continental margin between $15^{\circ} 38^{\prime} \mathrm{S}$ and $27^{\circ} 57^{\prime} \mathrm{S}$ (Angola and Namibia). Limnol Oceanogr 44(3):650-661

Fossing H, Jørgensen BB (1989) Measurement of bacterial sulfate reduction in sediments: evaluation of a single-step chromium reduction method. Biogeochem 8:205-222

Giuliani S, Radakovitch O, Frignani M, Bellucci LG (2007) Short time scale variations of ${ }^{234} \mathrm{Th} /{ }^{238} \mathrm{U}$ disequilibrium related to mesoscale variability on the continental slope of the Gulf of Lions (France). Mar Chem 106:403-418

Gribsholt B, Kostka JE, Kristensen E (2003) Impact of fiddler crabs and plant roots on sediment biogeochemistry in a Georgia saltmarsh. Mar Ecol Prog Ser 259:237-251

Hall POJ, Aller RC (1992) Rapid, small-volume, flow injection analysis for $\Sigma \mathrm{CO}_{2}$ and $\mathrm{NH}_{4}^{+}$in marine and freshwaters. Limnol Oceanogr 37(5):1113-1119

Hensen C, Zabel M, Schulz HN (2006) Benthic cycling of oxygen, nitrogen and phosphorus. In: Schulz HD, Zabel M (eds) Marine geochemistry. Springer-Verlag Berlin Heidelberg New York, pp 207-240

Hung CC, Gong GC (2007) Export flux of POC in the main stream of the Kuroshio. Geophys Res Lett 34:1-6

Hyun JH, Kim D, Shin CW, Noh JH, Yang EJ, Mok JS,
Kim SH, Kim HC, Yoo S (2009a) Enhanced phytoplankton and bacterioplankton production coupled to coastal upwelling and an anticyclonic eddy in the Ulleung basin, East Sea. Aquat Microb Ecol 54:45-54

Hyun JH, Mok JS, Cho HY, Kim SH, Lee KS, Kostka JE (2009b) Rapid organic matter mineralization coupled to iron cycling in intertidal mud flats of the Han River estuary, Yellow Sea. Biogeochem 92:231-245

Hyun JH, Mok JS, You OR, Kim D, Choi DL (2010) Variations and controls of sulfate reduction in the continental slope and rise of the Ulleung Basin off the southeast Korean upwelling system in the East Sea. Geomicrobiol J 27:212-222

Hyun JH, Smith AC, Kostka JE (2007) Relative contribution of sulfate- and iron(III) reduction to organic matter mineralization and process controls in contrasting habitats of the Georgia saltmarsh. Appl Geochem 22:2637-2651

Jahnke RA, Jahnke DB (2000) Rates of C, N, P and Si recycling and denitrification at the US Mid-Atlantic continental slope depocenter. Deep-Sea Res I 47:14051428

Jahnke RA, Reimers CE, Craven DB (1990) Intensification of recycling of organic matter at the sea floor near ocean margins. Nature 348:50-54

Jørgensen BB (1978) A comparison of methods for quantification of bacterial sulfate reduction in coastal marine sediments, I. Measurement with radiotracer techniques. Geomicrobiol J 1:11-27

Jørgensen BB (1982) Mineralization of organic matter in the sea bed-the role of sulphate reduction. Nature 296:643645

Jørgensen BB (2006) Bacteria and marine biogeochemistry. In: Schulz HD, Zabel M (eds) Marine geochemistry. Springer-Verlag Berlin Heidelberg New York, pp 169206

Jørgensen BB, Kasten S (2006) Sulfur cycling and methane oxidation. In: Schulz HD, Zabel M (eds) Marine geochemistry. Springer-Verlag Berlin Heidelberg New York, pp 271-309

Lee T, Hyun JH, Mok JS, Kim D (2008) Organic carbon accumulation and sulfate reduction rates in slope and basin sediments of the Ulleung Basin, East/Japan Sea. Geo Mar Lett 28:153-159

Lovley DR, Phillips EJP (1988) Novel mode of microbial energy metabolism: organic carbon oxidation coupled to dissimilatory reduction of iron or manganese. Appl Environ Microbiol 54(6):1472-1480

Moran SB, Kelly RP, Hagstrom K, Smith JN, Grebmeier JM, Cooper LW, Cota GF, Walsh JJ, Bates NR, Hansell 
DA, Maslowski W, Nelson RP, Mulsow S (2005) Seasonal changes in POC export flux in the Chukchi Sea and implications for water column-benthic coupling in Arctic shelves. Deep-Sea Res II 52:3427-3451

Moran SB, Weinstein SE, Edmonds HN, Smith JN, Kelly RP, Pilson MEQ, Harrison WG (2003) Does ${ }^{234} \mathrm{Th} /{ }^{238} \mathrm{U}$ disequilibrium provide an accurate record of the export flux of particulate organic carbon from the upper ocean? Limnol Oceanogr 48(3):1018-1029

Park MH, Kim JH, Kim IS, Ryu BJ, Yu KM (2005) Tephrostratigraphy and paleo-environmental implications of Late Quaternary sediments and interstitial water in the western Ulleung Basin, East/Japan Sea. Geo Mar Lett 25:54-62

Parsons TR, Maita Y, Lalli CM (1984) A manual of chemical and biological methods for seawater analysis. Pergamon Press Oxford, $173 \mathrm{p}$

Phillips EJP, Lovley DR (1987) Determination of Fe(III) and $\mathrm{Fe}(\mathrm{II})$ in oxalate extracts of sediment. Soil Sci Soc Am J 51:938-941

Reimers CE, Jahnke RA, McCorkle DC (1992) Carbon fluxes and burial rates over the continental slope and rise off central California with implications for the global caron cycle. Global Biogeochem Cycles 6(2):199-224

Stookey LL (1970) Ferrozine-a new spectrophotometric reagent for iron. Anal Chem 42(7):779-781

Thamdrup B, Canfield DE (1996) Pathways of carbon oxidation in continental margin sediments off central Chile. Limnol Oceanogr 41(8):1629-1650

Thamdrup B, Canfield DE (2000) Benthic respiration in aquatic sediments. In: Sala OE, Jackson RB, Mooney HA, Howarth RW (eds) Methods in ecosystem science. Springer-Verlag Berlin Heidelberg New York, pp 86-103

Thamdrup B, Dalsgaard T (2000) The fate of ammonium in anoxic manganese oxide-rich marine sediment. Geochim Cosmochim Acta 64(24):4157-4164

Thamdrup B, Fossing H, Jørgensen BB (1994) Manganese, iron, and sulfur cycling in a coastal marine sediment, Aarhus Bay, Denmark. Geochim Cosmochim Acta 58(23):5115-5129

Walsh JJ (1991) Importance of continental margins in the marine biogeochemical cycling of carbon and nitrogen. Nature 350:53-55

Weber A, Riess W, Wenzhoefer F, Jørgensen BB (2001) Sulfate reduction in Black Sea sediments: in situ and laboratory radiotracer measurements from the shelf to 2000m depth. Deep-Sea Res I 48:2073-2096

Wollast R (1991) The coastal organic carbon cycle: fluxes, sources, and sinks. In: Mantoura RFC, Martin JM, Wollast $\mathrm{R}$ (eds) Ocean margin processes in global change. John Wiley \& Sons, pp 365-381

Wollast R (1998) Evaluation and comparison of the global carbon cycle in the coastal zone and in the open ocean. In: Brink KH, Robinson AR (eds) The Sea: The global coastal ocean: Processes and methods (Vol. 10). John Wiley \& Sons, pp 213-252

Wollast R (2002) Continental Margins-Review of geochemical settings. In: Wefer G, Billett D, Hebbeln D, Jørgensen BB, Schlüter M, Van Weering $\mathrm{T}$ (eds) Ocean margin systems. Springer-Verlag Berlin Heidelberg New York, pp 15-31

Yamada K, Ishizaka J, Nagata H (2005) Spatial and temporal variability of satellite primary production in the Japan Sea from 1998 to 2002. J Oceanogr 61:857-869

Received Aug. 11, 2010

Revised Sep. 1, 2010

Accepted Sep. 14, 2010 